\title{
KEMAMPUAN PEMECAHAN MASALAH PESERTA DIDIK EKSTROVERT DAN INTROVERT DENGAN MODEL PEMBELAJARAN GENERATIF
}

\author{
Roudhotul Hanana ${ }^{1}$, RR. Ettie Rukmigarsari ${ }^{2}$, Abdul Halim Fathani ${ }^{3 *}$ \\ ${ }_{1,2,3}$ Universitas Islam Malang \\ * Corresponding Author. Email: fathani@unisma.ac.id \\ Received: 8 Agustus 2019; Revised: 18 Agustus 2019 ; Accepted: 30 September 2019
}

\begin{abstract}
ABSTRAK
Tujuan penelitian ini adalah untuk mengetahui (1) Apakah ada perbedaan kemampuan pemecahan masalah matematika peserta didik ekstrovert yang diberi dan yang tidak diberi model pembelajaran generatif; (2) Apakah ada perbedaan kemampuan pemecahan masalah matematika peserta didik introvert yang diberi dan yang tidak diberi model pembelajaran generatif. Metode penelitian yang digunakan adalah metode kuantitatif dengan rancangan penelitian true eksperimen dengan jenis pretest-possttest control group design, dalam desain ini terdapat dua kelas yakni kelas eksperimen diberi perlakuan model pembelajaran generatif dan kelas kontrol tidak diberi perlakuan model pembelajaran generatif. Sampel dalam penelitian ini adalah peserta didik kelas XI IAI 1 dan XI IAI 2. Teknik analisis data pada penelitian ini diantaranya adalah: (1) Uji Normalitas; (2) Uji perbandingan data pretest; (3) Uji perbandingan data posttest. Berdasarkan analisis data kuantitatif dengan menggunakan Software SPSS 23 diperoleh kesimpulan (1) Terdapat perbedaan yang signifikan kemampuan pemecahan masalah matematika peserta didik ekstrovert yang diberi $(90,13 \pm 6,50)$ dan yang tidak diberi $(81,33 \pm 5,12)$ model pembelajaran generatif; (2) Terdapat perbedaan yang signifikan kemampuan pemecahan masalah matematika peserta didik introvert yang diberi $(82,47 \pm 4,76)$ dan yang tidak diberi $(75,33 \pm 7,40)$ model pembelajaran generatif.

Kata Kunci: generatif, pemecahan masalah, ekstrovert, introvert.

How to Cite: Hanana, R., Rukmigarsari, RR, E., \& Fathani, A, H. (2019). Kemampuan Pemecahan Masalah Peserta Didik Ekstrovert Dan Introvert Dengan Model Pembelajaran Generatif. Histogram: Jurnal Pendidikan Matematika, 3(2), $240 \quad-249 \quad$, doi: http://dx.doi.org/10.31100/histogram.v3i2.488

Permalink/DOI: http://dx.doi.org/10.31100/histogram.v3i2.488
\end{abstract}

\section{PENDAHULUAN}

Menurut Johnson dan Rising (Suherman, 2003), matematika merupakan pola berpikir, mengorganisasikan, pembuktian secara logis dan bahasa simbol yang didefinisikan dengan cermat, jelas dan akurat. Sedangkan Mustangin (Azizah, 2013) mengemukakan bahwa matematika berkenaan dengan ide atau gagasan yang terstruktur

This is open access article under the CC-BY-SA-license.

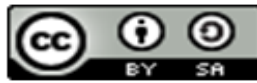




\section{Histogram: Jurnal Pendidikan Matematika, 3 (2), 2019 - 241 \\ Roudhotul Hanana, RR. Ettie Rukmigarsari, Abdul Halim Fathani}

secara logis dan berkaitan dengan konsep abstrak, matematika adalah suatu sistem yang hirarkis sehingga seseorang harus mempelajari suatu konsep secara berurutan.

Matematika merupakan mata pelajaran yang sangat penting di dalam pendidikan. Mata pelajaran matematika diajarkan sejak jenjang Sekolah Dasar (SD) sampai Perguruan Tinggi (PT), bahkan mungkin sejak Playgroup atau Taman Kanak Kanak. Pelajaran Matematika sering dianggap sebagai pelajaran yang menakutkan bagi sebagian besar peserta didik di sekolah karena matematika hanya berisi rumus-rumus, peserta didik juga menganggap bahwa matematika tidak bersinggungan dengan kenyataan kehidupan peserta didik.

Diantara mata pelajaran yang lain, hasil belajar matematika saat ini masih tergolong rendah. Hal ini dapat dilihat pada rendahnya rata-rata hasil tes Programme for International Student Assesment (PISA) dan Trends in International Mathemathics and Science Study (TIMSS). Secara internasional dua studi ini merupakan indikator hasil belajar matematika. Berdasarkan hasil PISA tahun 2015 kemampuan matematika peserta didik di Indonesia menduduki peringkat ke- 69 dari 76 peserta dengan perolehan rata-rata skor 403, sedangkan hasil TIMSS tahun 2015 kemampuan matematika peserta didik di Indonesia menduduki peringkat ke 44 dari 50 peserta dengan skor 397 dari 500 . Beberapa faktor yang menyebabkan rendahnya kemampuan matematika peserta didik adalah penyampaian materi pelajaran yang kurang menarik dan bervariasi, banyak guru yang masih menggunakan metode konvensional dan tidak tersedianya media pembelajaran.

Untuk menanggulangi hal-hal yang menyebabkan rendahnya kemampuan matematika peserta didik tersebut guru perlu menerapkan model pembelajaran yang berbeda dari sebelumnya, agar peserta didik lebih tertarik dalam mengikuti proses pembelajaran di kelas. Model pembelajaran yang digunakan disarankan yang lebih berorientasi peserta didik, yakni peserta didik lebih berperan aktif dalam proses pembelajaran, sedangkan guru berperan sebagai fasilitator. Proses interaksi yang selama proses pembelajaran tergantung pada model pembelajaran yang digunakan guru. Salah satu diantaranya adalah model pembelajaran generatif, yakni model pembelajaran yang megintegrasikan antara pengetahuan baru dengan pengetahuan terdahulu/sebelumnya.

Dengan menerapkan model pembelajaran generatif, guru dapat membimbing peserta didik dalam memecahkan masalah dengan menghubungkan pengetahuan yang telah mereka dapat dengan informasi yang baru. Krulik dan Rudnik (Hendriana, H., Rohaeti, E, E., \& Sumarmo, 2017) mengemukakan bahwa pemecahan masalah merupakan proses 


\section{Histogram: Jurnal Pendidikan Matematika, 3 (2), 2019 - 242 \\ Roudhotul Hanana, RR. Ettie Rukmigarsari, Abdul Halim Fathani}

penyelesaian masalah yang belum dikenal dengan menggunakan pengetauan, keterampilan dan pemahaman yang diperoleh. Polya (Hendriana, H., Rohaeti, E, E., \& Sumarmo, 2017) mengemukakan langkah-langkah pemecahan masalah sebagai berikut: a) memahami masalah meliputi: mengidentifikasi unsur yag diketahui, unsur yang ditanyakan, memeriksa kecukupan unsur untuk penyelesaian masalah; b)mengaitkan unsur yang diketahui dan ditanyakan dan merumuskannya dalam bentuk model matematika masalah; c) memilih strategi penyelesaian, mengelaborasi dan melaksanakan perhitungan atau menyelesaikan model matematika; d) menginterpretasi hasil terhadap masalah semula dan memeriksa kembali kebenaran solusi.

Adapun faktor internal yang mempengaruhi rendahnya kemampuan matematika peserta didik dalam proses pembelajaran salah satunya adalah tipe kepribadian yang dimiliki oleh peserta didik. Jung (Suryabrata, 2011) membedakan manusia menjadi dua tipe, yaitu: tipe ekstravers dan tipe introvers. Kedua tipe ini akan dimiliki oleh setiap individu, tetapi salah satu dari keduanya akan lebih dominan melekat pada setiap individu. Hal ini yang menyebabkan individu dapat dikelompokkan ke dalam satu bentuk tipe kepribadian tersebut. Seseorang dikelompokkan dalam salah satu tipe kepribadian tersebut berdasarkan jenis sikap yang lebih dominan dan lebih memberikan pengaruh terhadap dirinya.

Menurut (Feist, J., \& Feist, G, 2009), "ekstraversi adalah sebuah sikap yang menjelaskan aliran psikis ke arah luar sehingga orang yang bersangkutan akan memiliki orientasi objektif dan menjauh dari subjektif. Ekstrover akan lebih mudah untuk dipengaruhi oleh sekelilingnya dibanding oleh kondisi dirinya sendiri. Mereka cenderung untuk berfokus pada sikap objektif dan menekan sisi subjektifnya”. Menurut Jung (Feist, J., \& Feist, G, 2009), introversi adalah aliran energi psikis ke arah dalam yang memiliki orientasi subjektif. Introver memiliki pemahaman yang bak terhadap dunia dalam diri mereka, dengan semua bias, fantasi, mimpi, dan persepsi yang bersifat individu. Orang orang ini akan menerima dunia luar dengan sangat selektif dan dengan pandangan subjektif mereka.

Menurut Wena (Amelia, 2010), model pembelajaran generatif terdiri dari empat tahap, yaitu: (1) pendahuluan atau tahap eksplorasi; (2) tahap pemfokusan; (3) tahap tantangan; (4) tahap penerapan konsep. Dengan tahapan-tahapan tersebut diharapkan dapat membuat peserta didik berkepribadian ekstrovert dan introvert lebih aktif selama proses 


\section{Histogram: Jurnal Pendidikan Matematika, 3 (2), 2019 - 243 \\ Roudhotul Hanana, RR. Ettie Rukmigarsari, Abdul Halim Fathani}

pembelajaran, sehingga dapat meningkatkan kemampuan pemecahan masalah peserta didik tersebut.

Salah satu materi yang dipelajari di Sekolah Menengah Atas (SMA) adalah program linear. Program linear merupakan salah satu topik yang diajarkan di kelas XI Semester Ganjil. Beberapa materi prasyarat yang harus dikuasai peserta didik sebelum mempelajari materi program linear dalah materi tentang persamaan dan pertidaksamaan fungsi linear dua variabel. Beberapa materi yang akan dipelajari dalam bab ini adalah model matematika, fungsi objektif, dan nilai optimum.

Tujuan dari dilaksanakannya penelitian ini yang pertama adalah untuk mengetahui apakah ada perbedaan kemampuan pemecahan masalah matematik siswa ekstrovert yang diberi dan yang tidak diberi model pembelajaran generatif pada materi program linear kelas XI MA Unggulan darul Ulum Rejoso, dan yang kedua untuk mengetahui apakah ada perbedaan kemampuan pemecahan masalah matematik siswa introvert yang diberi dan yang tidak diberi model pembelajaran generatif pada materi program linear kelas XI MA Unggulan darul Ulum Rejoso.

\section{METODE PENELITIAN}

Rancangan penelitian yang digunakan merupakan penelitian eksperimen. Dimana menurut (Tanzeh, 2009) penelitian eksperimental merupakan suatu metode yang digunakan untuk mengetahui ada tidaknya pengaruh dari suatu alat, media atau kondisi yang dengan sengaja diberikan terhadap suatu gejala sosial berupa kegiatan dan perilaku seseorang atau kelompok individu. Dalam penelitian ini peneliti menggunakan desain true-eksperimen, menurut (Sugiyono, 2013) desain ini dapat mengontrol seluruh variabel luar yang dapat mempengaruhi jalannya eksperimen, dengan demikian kualitas pelaksanaan rancangan penelitian dapat menjadi tinggi. Penelitian ini menggunakan rancangan true experimental design karena peneliti telah memnuhi 3 syarat yakni pengambilan sampel secara acak, adanya kelas kontrol, dan adanya replikasi. Pengambilan sampel dalam penelitian ini menggunakan teknik cluster Random Sampling dimana peneliti mengambil sampel berkelompok secara acak. Kelas kontrol pada penelitian ini adalah kelas yang tidak diberi model pembelajaran generatif. Adapun Replikasi dalam penelitian ini adalah banyaknya siswa pada kelas sampel, pada penelitian ini banyaknya replikasi adalah 60 peserta didik. Untuk mengetahui keberhasilan proses pembelajaran dalam penelitian ini, maka peneliti menggunakan rancangan true experimental dengan jenis pretest-posttest control group 


\section{Histogram: Jurnal Pendidikan Matematika, 3 (2), 2019 - 244 \\ Roudhotul Hanana, RR. Ettie Rukmigarsari, Abdul Halim Fathani}

design. Dalam desain ini terdapat dua kelompok, yaitu kelompok eksperimen yakni kelompok yang diberi perlakuan model pembelajaran generatif dan kelompok kontrol yakni kelompok yang tidak diberi perlakuan model pembelajaran generatif.

Penelitian ini dilaksanakan di MA Unggulan Darul Ulum Rejoso, populasi dalam penelitian ini adalah seluruh peserta didik kelas XI MA Unggulan Darul Ulum Rejoso, sampel penelitian yang digunakan ialah kelas XI IAI 1 sebagai kelas eksperimen dan kelas XI IAI 2 sebagai kelas kontrol.

Dalam penelitian ini hanya terdapat variabel respon, yakni setiap variabel memberikan respon atas perlakuan model pembelajaran generatif yang diberikan. Variabel respon dalam penelitian ini ada dua yakni: kemampuan pemecahan masalah matematika peserta didik ekstrovert dan kemampuan pemecahan masalah matematika peserta didik introvert. Data pada penelitian ini bersumber dari nilai pretest dan nilai posttest kelas eksperimen dan kelas kontrol. Dimana nilai pretest digunakan untuk mengetahui kemampuan awal kedua kelas sama dan tidaknya. Pretest diberikan kepada peserta didik sebelum dilakukannya perlakuan pada kedua kelas. Setelah diberikan perlakuan terhadap kedua kelas, siswa akan diberikan soal posttest yang kemudian nilai dari kedua kelas tersebut akan dianalisi. Selain data dari nilai pretest posttest, peneliti juga mengambil data kepribadian peserta didik dengan menggunakan angket kepribadian.

Teknik pengumpulan data pada penelitian ini adalah dengan menggunakan kuesioner dan tes. Kuesioner yang dimaksud ialah angket tes kepribadian Eysenck Personality Inventory dengan jumlah pertanyaan 56 butir pertanyaan dengan pilihan jawaban ya dan tidak. Sedangkan Tes yang dimaksud adalah soal tes baik pretest maupuan posttest yang telah divalidasi oleh dosen dan guru.

Tabel 1. Blue Print Skala Eysenck's Personality Inventory

\begin{tabular}{llc}
\hline Tipe Kepribadian & \multicolumn{1}{c}{ Nomor item } & Jumlah \\
\hline Lie (L) & $16,12,18,24,30,36,42,48,52$ & 9 \\
Ekstraversion (E) & $1,3,5,8,10,13,15,17,20,22,25,27,29,32,34$, & 24 \\
& $37,39,41,44,46,49,51,53,56$ & \\
Neurotic (N) & $2,4,7,9,11,14,16,19,22,23,26,28,31,33$, & 23 \\
& $35,38,40,43,45,47,50,52,55$ & \\
\hline & \multicolumn{1}{c}{ Jumlah } & $\mathbf{5 6}$
\end{tabular}

(Sumber: Asterina, Tahun: 2012) 


\section{Histogram: Jurnal Pendidikan Matematika, 3 (2), 2019 - 245 \\ Roudhotul Hanana, RR. Ettie Rukmigarsari, Abdul Halim Fathani}

Teknik analisis data yang diguakan dalam penelitian ini antara lain: (1) Uji normalitas; (2) Uji perbandingan data pretest; (3) Uji perbandingan data posttest. Uji normalitas dalam penelitian ini menggunakan Software SPSS 23 dengan uji Saphiro-Wilk. Adapun kriteria keputusan yaitu bila nilai Sig atau $p$-value lebih besar dari taraf signifikansi $\alpha=0,05$ maka $H_{0}$ diterima yang berarti data terdistribusi normal dan sebaliknya jika nilai Sig atau $p$-value lebih kecil dari taraf signifikansi $\alpha=0,05$ maka $H_{l}$ diterima yang berarti data tidak terdistribusi normal. Sedangkan uji perbandingan data pretest menggunakan independent sample t-test dengan cara analyze - compare means - Independent sample ttest. Dengan kriteria pengambilan keputusan jika nilai Sig $>0,05$ berarti tidak ada perbedaan yang bermakna dan jika nilai Sig. $\leq 0,05$ berarti ada perbedaan yang bermakna. Sedangkan uji perbandingan data posttest menggunakan independent sample t-test dengan cara analyze - compare means - Independent sample t-test. Dengan kriteria pengambilan keputusan jika nilai Sig. $>0,05$ berarti ada perbedaan yang bermakna dan jika nilai Sig. $\leq$ 0,05 berarti ada perbedaan yang bermakna.

\section{HASIL DAN PEMBAHASAN}

Sebelum dilakukan uji perbandingan maka dilakukan uji normalitas terlebih dahulu. Untuk lebih jelas hasil uji normalitas tersebut disajikan dalam tabel 2 berikut:

Tabel 2. Hasil Uji Normalitas Data

\begin{tabular}{lllll}
\hline Variabel & $\boldsymbol{N}$ & Kelas & p_value & Distribusi \\
\hline Pretest & & & & \\
\hline Tipe Kepribadian & 15 & Eksperimen & 0,733 & Normal \\
Ekstrovert & 15 & Kontrol & 0,208 & Normal \\
Tipe Kepribadian & 15 & Eksperimen & 0,697 & Normal \\
Introvert & 15 & Kontrol & 0,977 & Normal \\
\hline Posttest & & & & \\
\hline Tipe Kepribadian & 15 & Eksperimen & 0,256 & Normal \\
Ekstrovert & 15 & Kontrol & 0,055 & Normal \\
Tipe Kepribadian & 15 & Eksperimen & 0,106 & Normal \\
Introvert & 15 & Kontrol & 0,702 & Normal \\
\hline
\end{tabular}

(Sumber: Data Primer, Tahun: 2018) 


\section{Histogram: Jurnal Pendidikan Matematika, 3 (2), 2019 - 246 \\ Roudhotul Hanana, RR. Ettie Rukmigarsari, Abdul Halim Fathani}

Keterangan: jika $p_{-}$value $<0,05$ berarti data tidak terdistribusi normal dan jika p_value $\geq 0,05$ berarti data terdistribusi normal.

Berdasarkan hasil uji Shapiro-Wilk pada Tabel 1 diperoleh bahwa semua data menunjukkan nilai $p$-value lebih besar dari taraf signifikansi $\alpha=0,05$ yang berarti bahwa data pretest dan posttest baik kelas eksperimen maupun kela kontrol terdistribusi normal. Jadi data pretest dan data posttest baik kelas eksperimen maupun kelas kontrol telah memenuhi uji prasyarat parametrik, yaitu data terbukti terdistribusi normal. Selanjutnya data telah siap dianalisis lebih lanjut dengan uji statistik parametrik guna membuktikan hipotesis penelitian yang telah diajukan.

Untuk lebih jelasnya hasil uji perbandingan data pretest tersebut disajikan dalam tabel 3 berikut:

Tabel 3. Hasil Perbandingan Data Pretest

\begin{tabular}{lccc}
\hline \multicolumn{1}{c}{ Variabel } & $\begin{array}{c}\text { Kelas Eksperimen } \\
\text { Mean } \pm \text { SD }\end{array}$ & $\begin{array}{c}\text { Kelas Kontrol } \\
\text { Mean } \pm \text { SD }\end{array}$ & p_value \\
\hline $\begin{array}{l}\text { KPMM Tipe Kepribadian } \\
\text { Ekstrovert }\end{array}$ & $47,27 \pm 10,88$ & $42,40 \pm 9,68$ & 0,227 \\
$\begin{array}{l}\text { KPMM Tipe Kepribadian } \\
\text { Introvert }\end{array}$ & $42,27 \pm 9,63$ & $42,87 \pm 9,30$ & 0,863 \\
\hline
\end{tabular}

(Sumber: Data Primer, Tahun: 2018)

Keterangan: jika $p_{-} v a l u e>0,05$ berarti tidak ada perbedaan yang bermakna dan jika p_value $\leq 0,05$ berarti ada perbedaan yang bermakna.

Berdasarkan hasil uji perbandingan pada Tabel 2, data pretest kemampuan pemecahan masalah matematika sampel berkepribadian ekstrovert kelas eksperimen dan kelas kontrol diperoleh $p_{\text {_value }}=0,227>0,05$ dengan rerata kemampuan pemecahan masalah peserta didik ekstrovert kelas eksperimen $(47,27 \pm 10,88)$ dan rerata kemampuan pemecahan masalah matematika peserta didik ekstrovert kelas kontrol $(42,40 \pm 9,68)$ yang berarti tidak ada perbedaan yang bermakna atau kedua sampel memiliki rata-rata kemampuan awal yang sama. Demikian pula dengan data pretest kemampuan pemecahan masalah matematika sampel berkepribadian introvert kelas eksperimen dan kelas kontrol diperoleh $p_{\text {_value }}=0,863>0,05$ dengan rerata kemampuan pemecahan masalah matematika peserta didik introvert kelas eksperimen $(42,27 \pm 9,63)$ dan rerata kemampuan pemecahan masalah matematika peserta didik introvert kelas kontrol 


\section{Histogram: Jurnal Pendidikan Matematika, 3 (2), 2019 - 247 \\ Roudhotul Hanana, RR. Ettie Rukmigarsari, Abdul Halim Fathani}

$(42,87 \pm 9,30)$ yang berarti tidak ada perbedaan yang bermakna atau kedua sampel memiliki rata-rata kemampuan awal yang sama.

Untuk lebih jelasnya hasil uji perbandingan data posttest tersebut disajikan dalam tabel 4 berikut:

Tabel 4. Hasil Uji Perbandingan Data Posttest

\begin{tabular}{lllc}
\hline Variabel & $\begin{array}{l}\text { Kelas Eksperimen } \\
\text { Mean } \pm \text { SD }\end{array}$ & $\begin{array}{l}\text { Kelas Kontrol } \\
\text { Mean } \pm \text { SD }\end{array}$ & p_value \\
\hline $\begin{array}{l}\text { KPMM Tipe Kepribadian } \\
\text { Ekstrovert }\end{array}$ & $90,13 \pm 6,50$ & $81,33 \pm 5,12$ & 0,000 \\
$\begin{array}{l}\text { KPMM Tipe Kepribadian } \\
\text { Introvert }\end{array}$ & $82,47 \pm 4,76$ & $75,33 \pm 7,40$ & 0,004 \\
\hline
\end{tabular}

(Sumber: Data Primer, Tahun: 2018)

Keterangan: jika p_value > 0,05 berarti ada perbedaan yang bermakna dan jika p_value $\leq 0,05$ berarti ada perbedaan yang bermakna.

Berdasarkan hasil uji t sampel bebas (independent sample t test) pada Tabel 3 menunjukkan bahwa ada perbedaan yang bermakna $(p=0,000<0,05)$. Dimana rerata nilai posttest kemampuan pemecahan masalah matematika peserta didik berkepribadian ekstrovert antara kelas eksperimen $(90,13 \pm 6,50)$ dengan kelas kontrol $(81,33 \pm 5,12)$. Tampak nilai rerata kemampuan pemecahan masalah matematika peserta didik berkepribadian ekstrovert pada kelas eksperimen lebih besar nilainya dibandingkan dengan nilai rerata kemampuan pemecahan masalah matematika peserta didik berkepribadian ekstrovert pada kelas kontrol. Hal ini berarti bahwa peserta didik berkepribadian ekstrovert yang diberi perlakuan model pembelajaran generatif akan menunjukkan kemampuan pemecahan masalah matematika yang lebih tinggi dibandingkan dengan yang tidak diberi perlakuan model pembelajaran generatif. Dengan kata lain model pembelajaran generatif dapat meningkatkan kemampuan pemecahan masalah matematika peserta didik berkepribadian ekstrovert. Jadi, hipotesis pertama terbukti, yaitu terdapat perbedaan kemampuan pemecahan masalah matematika peserta didik ekstrovert yang diberi dan tidak diberi model pembelajaran generatif pada materi program linear kelas XI MA Unggulan Darul Ulum Rejoso tahun pelajaran 2017/2018.

Demikian pula dengan hasil perbandingan data posttest kemampuan pemecahan masalah matematika peserta didik berkepribadian introvert ada perbedaan bermakna 


\section{Histogram: Jurnal Pendidikan Matematika, 3 (2), 2019 - 248 \\ Roudhotul Hanana, RR. Ettie Rukmigarsari, Abdul Halim Fathani}

$(p=0,004<0,05)$. Dimana rerata nilai posttest kemampuan pemecahan masalah matematika peserta didik berkepribadian introvert antara kelas eksperimen $(82,47 \pm 4,76)$ dengan kelas kontrol $(75,33 \pm 7,40)$. Tampak nilai rerata kemampuan pemecahan masalah matematika peserta didik berkepribadian introvert pada kelas eksperimen lebih besar nilainya dibandingkan dengan nilai rerata kemampuan pemecahan masalah matematika peserta didik berkepribadian introvert pada kelas kontrol. Hal ini berarti bahwa peserta didik berkepribadian introvert yang diberi perlakuan model pembelajaran generatif akan menunjukkan kemampuan pemecahan masalah matematika yang lebih tinggi dibandingkan dengan yang tidak diberi perlakuan model pembelajaran generatif. Dengan kata lain model pembelajaran generatif dapat meningkatkan kemampuan pemecahan masalah matematika peserta didik berkepribadian introvert. Jadi, hipotesis kedua terbukti, yaitu terdapat perbedaan kemampuan pemecahan masalah matematika peserta didik introvert yang diberi dan tidak diberi model pembelajaran generatif pada materi program linear kelas XI MA Unggulan Darul Ulum Rejoso tahun pelajaran 2017/2018.

\section{KESIMPULAN DAN SARAN}

\section{A. Kesimpulan}

Berdasarkan hasil penelitian mengenai pengaruh model pembelajaran generatif terhadap kemampuan pemecahan masalah matematika ditinjau dari tipe kepribadian peserta didik pada materi program linear kelas XI MA Unggulan Darul Ulum Rejoso tahun pelajaran 2017/2018, diperoleh kesimpulan sebagai berikut. (1) Terdapat perbedaan yang signifikan kemampuan pemecahan masalah matematika peserta didik ekstrovert yang diberi $(90,13 \pm 6,50)$ dan yang tidak diberi $(81,33 \pm 5,12)$ model pembelajaran generatif pada materi program linear kelas XI MA Unggulan Darul Ulum Rejoso tahun pelajaran 2017/2018; (2)Terdapat perbedaan yang signifikan kemampuan pemecahan masalah matematika peserta didik introvert yang diberi $(82,47 \pm 4,76)$ dan yang tidak diberi $(75,33 \pm 7,40)$ model pembelajaran generatif pada materi program linear kelas XI MA Unggulan Darul Ulum Rejoso tahun pelajaran 2017/2018.

\section{B. Saran}

Dari hasil penelitian ini diharapkan dapat memberikan sumbangan gagasangagasan dalam upaya meningkatkan kualitas pembelajaran matematika, khususnya dalam melatih kemampuan pemecahan masalah matematika peserta didik. Oleh karena itu, 


\section{Histogram: Jurnal Pendidikan Matematika, 3 (2), 2019 - 249 \\ Roudhotul Hanana, RR. Ettie Rukmigarsari, Abdul Halim Fathani}

diberikan saran sebagai berikut: (1) Guru dapat menerapkan model pembelajaran generatif untuk pembelajaran yang lain sesuai dengan sintaks model pembelajaran generatif; (2) Sekolah diharapkan dapat memberikan dukungan dengan memaksimalkan sarana prasarana sekolah agar supaya guru dapat menerapkan berbagai model maupun metode pembelajaran untuk meningkatkan kualitas pendidikan di sekolah; dan (3) Peneliti dapat melakukan penelitian lebih lanjut dengan mengembangkan model pembelajaran generatif pada tingkat dan konsep yang berbeda dengan memperhatikan rancangan pembelajaran yang lebih efektif dan efisien sehingga kemampuan pemecahan masalah matematika peserta didik lebih optimal.

\section{DAFTAR PUSTAKA}

Amelia, M. . (2010). Pengaruh Model Pembelajaran Generatif terhadap Kemampuan Koneksi Matematika Siswa. UIN Jakarta.

Asterina, D. A. (2012). Hubungan Tipe Kepribadian dengan Perilaku Asertif Mahasiswa Fakultas Psikologi UIN Maulana Malik Ibrahim Malang. UIN Maulana Malik Ibrahim Malang.

Azizah, N. (2013). Pengaruh Pendekatan Contextual Teaching and Learning (CTL) terhadap Kemampuan Berpikir Kritis Matematika Siswa Kelas VII SMP Negeri 2 Besuk Probolinggo Tahun Pelajaran 2012/2013. Universitas Islam Malang.

Feist, J., \& Feist, G, J. (2009). Theories of Personality, 7th ed. Jakarta: Salemba Humanika.

Hendriana, H., Rohaeti, E, E., \& Sumarmo, U. (2017). Hard Skills dan Soft Skills Matematik Siswa. Bandung: PT Refika Aditama.

Sugiyono. (2013). Metode Penelitian Pendidikan Kuantitatif, Kualitatif, dan R\&D. Bandung: Alfabeta.

Suherman, E. (2003). Strategi Pembelajaran Matematika Kontemporer. Bandung: PT. Remaja Rosda Karya.

Suryabrata, S. (2011). Psikologi Pendidikan. Jakarta: PT. Raja Grafindo Persada.

Tanzeh, A. (2009). Pengantar Metode Penelitian. Yogyakarta: Teras. 